\title{
European and American Christian Missions and Nigeria's National Development (1840-1960)
}

\author{
B.C.D. Diara \\ Department of Religion and Cultural Studies \\ University of Nigeria, Nsukka- Nigeria \\ Nche George Christian \\ Department of Religion and Cultural Studies \\ University of Nigeria, Nsukka- Nigeria
}

\section{Doi:10.5901/jesr.2013.v3n10p89}

\begin{abstract}
The socio-economic conditions of Africa during the advent of the European and American Christian missions were deplorable and piteous. This was particularly the case with that part of the continent that was later named Nigeria by the British colonial authority. To help or not to help the people economically therefore became one of the greatest problems of the missionaries owing to the vastness of the area and the large population of the people occupying it. Nevertheless, the missionaries saw the socio-economic assistance to the less-privileged and poor natives as a missionary imperative. The solution was found in the system of indirect socio-economic assistance of the converts. This was inherent in the works of all the missionary groups that brought the Christian gospel to Africa. Thus, the Christian missions laboured to develop the Nigerian nation since the 19th century. The main thrust of this paper is to objectively evaluate the general impacts of the establishment of Christian missions in Nigeria on her people and nationhood. It is aimed at challenging the Christian leaders of today to re-appraise their commitment to the social aspect of the Church's call. While using an analytical and descriptive historical approach to the study of the activities of the Christian missions in Nigeria between the 19th and the 20th centuries, this research has discovered that the contributions of the European and American missionaries who undertook pioneer missionary work in the country have been under-estimated in earlier historical records. The missionaries actually contributed immensely to the development of Nigerians individually and corporately in many areas including Education, Medicare, Agriculture and commerce.
\end{abstract}

Keywords: christian, missions, national, development, education

\section{Introduction}

The Niger area (that part of Africa that was named Nigeria during the colonial era by the British authority) was an over-ripe missionary field in the $19^{\text {th }}$ century. This was very challenging to the Christian missionaries who came from Europe and America to evangelize the area owing to the grave socio-economic conditions in which the people were living. Corroborating this fact, Baur (1994) wrote:

On arrival, the Christian missionaries who came to Africa (Nigeria inclusive) in the 19th century found themselves struggling to avoid the danger of creating what in China was described as 'Rice Christians'. This is a situation where the motive of conversion to the Christian faith becomes material help instead of internal acceptance of the Christian faith. This 
also posed the danger of creating beggars in the society (p.419).

Nevertheless, the missionaries saw the need to help the people out of their socio-economic problems and they did so in many ways. In the first place, there is the profit of missionary education, enabling a significant part of the population to earn their living through salaried work or to start their own trades. Health care was also worthwhile: it liberated many Nigerians, especially those from the South, from so many diseases and premature death, giving them more strength and joy to work for their livelihood. There was also the introduction of cash crops which slowly developed into other major money spinners of national economies and the population of labour through the construction and maintenance of mission buildings, the employment to mission personnel: casual labour in garden, fields and roads.

The different Christian missions made significant contributions to the socio-economic development of Nigeria in many areas of human life such as Education, Medicare, agriculture, commerce, politics, etc. Nevertheless, Education and Medicare are the major areas in which the missionaries made impact on national development in most African nations. For the purpose of this paper, we shall treat all the Christian missions who laboured in Nigeria during the $19^{\text {th }}$ and $20^{\text {th }}$ centuries as a single entity in terms of their socio-economic impacts on the Nigerian nation.

\section{The Establishment of Christian Missions in Nigeria}

The Christian Church took its origin from Jerusalem, the historic capital city of Israel. It was from Jerusalem that the Church expanded to other parts of the world. Jerusalem was to remain important to the Christian Church until the Roman Army destroyed the city in A.D. 70, after which tine, Rome became the headquarter of the Christian Church (Dowley, 1990). The rest of the Roman world which comprised mostly of European countries may have received the Christian gospel as early as the $2^{\text {nd }}$ Century.

In the $15^{\text {th }}$ to the $17^{\text {th }}$ centuries, the Portuguese, the French and the Italian Catholic governments and missionary bodies made several efforts to evangelize parts of what is known today as Nigeria, particularly Benin and Warri areas. But their efforts ended in fiasco. Later on, in the later part of the $18^{\text {th }}$ century, the British government and some English missionary and charitable groups became interested in West Africa. Freetown in Sierra Leone was consequently established as a settlement for freed slaves in 1787. In 1841, the British government sponsored the first expedition to the Niger with the aim of establishing a Christian mission in the area. Ajayi Crowther, a Nigerian of the Yoruba extraction, one of the freed African slaves in Sierra-Leone happened to be part of this expedition.

The year 1841 thus marked the beginning of the movement to re-establish Christianity in Nigeria after the failure of the earlier Catholic Missionary efforts in Benin and Warri. This phase, however, was only the "nursery" stage in preparation for the success period of the missionary work in Nigeria that came later with the British rule. Between 1841 and 1900 Nigeria witnessed the work of five missionary societies, namely, the Church Missionary Society of the Church of England, the Wesleyan Methodist Missionary Society from England, the United Presbyterian Church of Scotland, the Southern Baptist Convention of the United States, and the French Catholic Society for African Missions (Ajayi, 1965).

There were some significant differences between these different missionary societies, both in doctrine and missionary approach. Each missionary society tended to emphasize those things that differentiated then from all others. But the contribution of each mission to the common factor of Christian missionary presence in Nigeria was not equal in men, material or significance. Initially, the Anglican Mission was the largest and the most significant, being part of the established church based in London the home of the colonial government. For this reason, the Church Missionary Society had the greatest influence on the British government and its missionaries were actively connected with the government sponsored Niger Expedition of 1841. 
The Methodist was the first to establish their mission in Nigeria, precisely at Badagry in 1842 but they were poorly represented. The Anglicans (CMS) established in Badagry later the same year and in Abeokuta in 1846, and hence led the missionary expansion into other parts of the Yoruba land. They established on the Niger (Igbo land) later in 1857 from where they extended the mission southwards to Delta and Rivers areas and northwards to Lokoja and beyond.

While the Methodists had only a short-lived mission station on the Niger at Egga, the Anglicans had several stations both on the Niger and in Delta areas. The Presbyterians arrived in Calabar in 1846 where they concentrated their efforts most exclusively with only a few outstations on the Cross River. The Baptists established their first station at Ijaye in 1853, and expanded into Yoruba hinterland but their work was interrupted following the American Civil War, and they had to start all over again after 1875 (Ajayi, 1965).

The Roman Catholic Mission came later than all others, in 1867, at Lagos. But hardly had they arrived when the Franco-Prussian War and the consequent civil disturbances in France disrupted their work (Ajayi, 1965). Outside Lagos, they were just making their initial contacts after 1875. The Holy Ghost Fathers arrived at Onitsha in 1885, 28 years after the arrival of the Church Missionary Society.

Missionary expansion became largely incidental to the establishment of the colonial rule in the Country between 1891 and 1960. It was from 1841 to 1891 and 1900 to 1960 that missionary work had its distinctive significance in Nigeria. It was in these periods that the missionaries had a greater measure of initiative and their work had its own decisive influence on Nigerians apart from the colonial influence.

\section{Abolition of Slave Trade}

The abolition of slave trade which was achieved through the efforts of the Church Missionary Society (C.M.S) of the Church of England was particularly beneficial to Nigeria as one of the freed slaves who became a Christian in Sierra-Leone and later joined the Anglican mission to Nigeria was a Nigerian from the Yoruba extraction. He was by name Samuel Ajayi Crowther, baptized in 1842, ordained in 1845 and consecrated Bishop in 1864 (Adiele, 2001).

Slave trade was started by the Portuguese in 1441 by one of explorers named Gonzalves who returned to Lisbon with some African slaves after visiting West African Coast (Agha, 1999). The Dutch entered the trade when they conquered Brazil and took over her plantations. By this time the Dutch and the Portuguese were the leading slave trading nations. Britain and France took over the lead in the eighteenth century. Because of the large profits that accrued from the trade, European monarchs gave official backing to the traders to carry on with the trade in the interest of their national prosperity. However, when all the evils connected with slave trade became clearly known, many good Christians and Christian Organizations began to speak openly against its continuation. The C.M.S. preached for the abolition of slave trade on the ground of brotherly love and sympathy as prescribed in the Christian Bible. With the passing of time, the movement for abolition of slave trade became influential even in the British Parliament.

Victory crowned the labours of the C.M.S. on $23^{\text {rd }}$ February, 1807 when the back of the opposition against abolition of slave trade was broken. The battle, however, continued for complete emancipation until age and poor health forced the leader of the Evangelicals, William Wilberforce, out of the parliament. The skills of a young evangelical named Thomas Fowel Buxton were immediately enlisted and he assumed the leadership of the "Holy enterprise". On $25^{\text {th }} \mathrm{July}, 1833$, four days before Wilberforce died, the reality of the passage of the Emancipation Act by the British Government came, freeing slaves throughout the British Empire (Shelly, 1970:388).

\section{Economic Empowerment to Slave Dealers}

Consequent upon the successful abolition of slave trade, the British Government signed treaties 
with the countries that were engaged in slavery and slave trade, yet the trade continued in secret. Britain went further to make treaties with individual African chiefs, who supplied slaves in order to eradicate the system from its root. In addition to the treaties, the British Government paid some compensation to African Chiefs, including Nigerians, to stop selling their subjects to oversea countries. For instance, in 1839 Britain signed a treaty with King Pepple of Bonny with a compensation of annual present of the value of 2,000 dollars for five years. Also, in 1842 Britain made treaties with chiefs Eyamba and Eyo of Duke Town and CreekTown in old Calabar for a compensation of 2000 dollars each annually (Okafor, 1989).

Although, it was not the Christian mission that directed the payment of compensations to Nigerian slave dealers as described above, it was her effort through the instrumentality of the Church Missionary Society of the Anglican Church that brought about it. Therefore the gesture was indirectly that of the Christian missions and it must have in one way or the other contributed to the development of Nigeria as a country.

\section{Development of African Litreature}

The first step towards missionary education in Africa was taken in Freetown in Sierra Leone. In the settlement for freed slaves at Freetown, there was the problem of ethnic loyalties among the liberated slaves, hence while attempts were being made to hold them together, there was continuity of old values, such as holding fastidiously to ethnic biases. These gave rise to the scientific study of native languages and subsequent development of African literature. This later led to the establishment of schools and introduction of Western education in Africa and Nigeria in particular (Okeke. 1994).

The development of African Literature was paramount in the evangelization of African and Nigeria in particular. T. J. Bowen (1848) observed that for the people to receive the Gospel, "they must have Bible and must have the art to make them or money to buy them, they must read the Bible, and this implies instruction". The Christian missionaries devoted all their efforts, within their thin resources to the study of Nigerian languages -Efik, Igbo, and Yoruba, reducing them to writing.

They missionaries studied the different Nigerian languages in order to facilitate evangelism in the land. They first produced Grammar and Dictionary books in the Yoruba language. The Scottish Presbyterian mission at Calabar developed the Efik alphabets and language and in 1874 Goldie published the Efik Dictionary, the Efik Grammar in Efik and in English. The study and production of native language in Nigeria facilitated the preaching as well as thee growth and development of Nigeria.

No less contribution was made by the missionaries in the translation of the Bible into local languages. This made it possible for the Nigerian converts to read the Bible effectively. They produced New Testament translation, Primers, hymns and sermons which still remain the standard work on the languages. The missionaries devoted considerable efforts to the development of some local languages as noted above.

\section{Establishment of Western Education}

The establishment of Western education in Nigeria could well be described as the barometer of the country's development hence schools were the most important missionary social institutions in the country. The greater number of children went or were sent to schools in order to have the white man's knowledge, the secret of his power, and mostly, to learn in order to get a job. Whatever the motives in the historical and sociological perspectives may be, the mission schools were the greatest service done to Nigerian people by European missionaries.

Education was also a stepping-stone in the emancipation of women, one of the greatest achievements of the missions besides general education. The school gave to the girls a new self 
consciousness and prepared them to earn their own living as teachers, nurses, etc. This liberated them from cultural restrictions thereby making them independent in choosing their life careers, husbands and in running their family affairs. Education was also a factor for professional training. In addition to general education, which gave the educated Nigerian the opportunity to secure the white-collar jobs, special schools provided opportunities for professional training and progress. The Europeans established Teachers' Training Colleges, Nursing Schools and Secondary Schools, which turned out teachers, nurses and clerks respectively among Nigerian natives.

Nigerian natives who received basic education from the European missionaries at Sierra Leone were drafted into villages and towns outside Abeokuta, Lagos, Ibadan and Onitsha which were the main Christian centres at the time where Europeans were directly responsible for running of the missionary schools. In the villages, the educated natives too could start evangelization of other natives through education and preaching of the word. In other words, Sunday schools were established in which those who could read and write in Yoruba and I gbo languages were assigned to teach. By this time, that was, before the $20^{\text {th }}$ century, there was no formal schools recognized by government in rural areas. In fact, government was only based in Lagos then (Adebiyi, 1994). By this time, the European missionaries spearheaded the task of educating the Nigerian children with the aim that they would be converted and taught how to read and write the major languages of the people and hence be used for the work of the mission in their areas.

Thus, initially, the missions adopted native languages, namely vernacular, as language of instruction in their schools. This implies that missionary education in Nigeria was introduced in stages. The first was literacy education followed by commercial/industrial education, then the Secondary and Grammar school education and finally, the Teacher's Training Education.

It was Ali Mazrui, a Muslim who first made the most pungent appraisal of the Christian missionary education in Africa in his article titled "Churches and Multinationals in the Spread of Modern Education" (Third World Quarterly (i) 1979). He however, claimed that the role of missionary schools in Africa was paradoxical in that they created what he called "techno-cultural gap" that did not make for significant social development. By this he meant that missionary education in Africa did not initiate technological culture and as such it could not effectuate meaningful development in the Continent. Grimley and Robinson in Agha (2012) on the other hand, affirm that the Christian missionaries made very significant contribution to general development in Africa through the introduction of both Primary and Secondary education. However, Basil Davidson in Agha (2012) agrees with Mazrui that missionary schools provided an inferior education for the people who were said to be inferior. This observation is relatively true in relation to the type of education that existed in the Whiteman's homeland at the time. In any case, the fact of low standard of education introduced by European missionaries in Africa could be attributed to the low academic qualifications of those who volunteered to come to minister to the Africans.

The desire for Western Education, according to Falk (197:435) promised to bring quick results in evangelization and education of the people of Africa. The result was that it produced a literate Christian laity who in turn served the missionaries as catechists, teachers and clerks. The missionaries imbibed the Biblical principles of training a child in the way he should go and the promise that later in life he will not depart from the training (Prov. 22:6). The children came to the mission schools and received both secular and religious education simultaneously. This prepared them for later life. The school has since then produced many eminent scholars, politicians, teachers, technicians, civil servants, leaders in key posts and positions in Nigeria. These people were instrumental to the development of Nigeria as a Nation.

\section{Establishment of Legitimate Trade and Agriculture}

Sequel to the success of the abolition of slave trade which gave rise to the planting of Christianity in Nigeria, the missionaries did not only preach the gospel in the Country. They assisted in reestablishing the legitimate trade on which European nations hitherto traded with Africans before 
the slave trade such as pepper, gum-arabic and Bini-cloth. In this way, they introduced European system of commerce in Nigeria in place of the illegal trade on slaves. Industrial institutions were established to teach carpentry, bricklaying, dyeing, etc. (Okeke, 1994). New crops hitherto not found in Nigeria were also introduced by the missionaries.

Table: Showing food crops and plants introduced in West Africa by Missionaries

\begin{tabular}{|c|c|c|c|c|c|c|}
\hline Root and Tuber Crops & Beverage Crops & $\begin{array}{c}\text { Vegetable } \\
\text { Crops }\end{array}$ & Spices & Fruit Crops & Oil Crops & Cereal Crops \\
\hline & & & & & & \\
\hline Carrot & Cocoa & Tomatoes & Ginger & Orange & Sun flower & Maize \\
\hline Yam, Cassava & Coffee & Amaranthus & Pepper & Sweet Orange & Soya Beans & Wheat \\
\hline Potato-Sweet & Kolanut & Onion-Sp. & Onion & & Oil Palm & Millet \\
\hline Potato-Irish & Cane Sugar & Okro & & Tangrm & Rubber Tree & Guinea Corn \\
\hline Cocoyam & & Cauliflower & Garlic & Grape Orange & & Barley \\
\hline & & Spinach & & & Groundnut & Dats \\
\hline & & Lettuce & & Banana & Mellon & Rice \\
\hline & Bitter Leaf & & Plantain & Coconut & \\
\hline & & & Pine & Cotton & \\
\hline & & & & Apple & & \\
\hline & & & & Mango & & \\
\hline & & & & Cashew & & \\
\hline
\end{tabular}

Source: Agha (2012)

Plantain agriculture (Model Farm) was started with numerous other food crops and plants. In the field of scientific agriculture and farm settlement in Nigeria, it was Fr. Borghero of the Roman Catholic mission who was the first to establish a farm settlement along a nine-mile strip of farm land along the Coast near Badagry. The farm was called "St. Joseph at Topo". It was established in 1975 and, it was first of its kind. Different types of foreign crops were introduced and cultivated in the farm for distribution to farmers e.g. cassava, oranges, cane sugar, coca trees, potatoes, yam, banana, and robber tress to name jus a few. The native families who had become Christians lived and farmed the land and paid for the use of the land in kind.

In $1880 \mathrm{Fr}$. Bell, who was the superior of the station described the condition for admission thus: "We admit on the land of the mission families wishing to put themselves under the rules we have imposed. They cultivate the land for their own profit except for a little rent paid in kind and by helping to clear further areas of strip of land" (Agha, 2012). The farm provided food for the missionaries and their workers, sanatorium for the sick and sanctuary for the oppressed (Ajayi, 1969).

Through the Norwegian Church, the Presbyterian Church established a farm land at I kwo in 1962. The church introduced foreign crops like Rice, Mango, Pineapple, Yam, Plantain, Maize, varieties of beans among others. The Church introduced scientific methods of cultivation, cooperative system of farming which enabled the people to be well established. The farm land was handed over to Anambra State in 1986 and was renamed "Anambra College of Agriculture and now it is known as Ebonyi College of Education, Ikwo". In 1972 the Presbyterian mission established the Yakurr Agricultural project aimed at helping the citizens of the area to be established for a better ling.

\section{Medical Services and Institutions}

Before the arrival of the European missionaries in Nigeria, the mortality rate among the people was 
so high. There were no known medicines to cure some very deadly diseases, which went wild rapidly and caused a heavy death toll among the people. Besides there was total lack of knowledge concerning many of these diseases. In many cases four out of five children died before they were two years old. Some of the most common diseases, which were major causes of death, included malaria fever, dysentery, diarrhea, and sleeping sickness. When the missionaries came to Nigeria and found the magnitude of mortality they felt compassion for the people and therefore, decided to leave no stone unturned until the solution was found.

Medical services occupied a second place in the missionary activity of the pioneer Christian Missions in Nigeria, second only to the actual preaching of the gospel. Just as Christ was primarily moved by genuine compassion to heal the sick, so also the European missionaries who came to Nigeria in Christ's name were moved not only to preach the gospel in words but also to do so through healing the sick. No doubt, for the pioneer missionaries their medicine chest was like a magical box working miracle of healing and winning the people's confidence where their preaching would have failed. In rural areas simple medical care was until quite recently part of a missionary's daily routine.

This would have been the proper task of the government but the colonial government was even slower in becoming aware of their duty to provide health care for their citizens than they had been in accepting their responsibility for education. Government support for mission hospitals was again in the form of grants. The Christian missionaries, the Roman Catholic and the Protestant Missions, were more responsible than the government in this respect. According to Baur (1998:416) comparably, the Protestants were well ahead in this respect and the Anglican missionaries were the pioneers. A shining example was the pioneering Anglican medical services in Igboland through the Iyienu Hospital. According to Onyeidu (2001: 41) "Perry Brown who was stationed at Lokoja was the first medical staff of the Anglican Mission in Niger Diocese". Then, that was, about the year 1883, Niger Diocese was the whole of the Country Nigeria apart from the Yorubaland. This was in the year 1883.

Achunike (1995) asserts that a hospital was established in Onitsha in 1893. In September, 1905 the Mary Slessor Hospital was established at Itu by the Church of Scotland Mission (C.S.M). The same group started mission in Uwana on $25^{\text {th }}$ October, 1888 and a mini-hospital in 1913, which is now known as the Presbyterian J oint Hospital. The Church Missionary Society (C.M.S.), the Church of Scotland Mission (C.S.M.) and the Methodist Mission jointly established the Queen Elizabeth Hospital in Umuahia on $24^{\text {th }}$ March 1956. In 1896, the C.M.S. opened a hospital with numerous maternities at Dobinson and this was later transferred to Iyienu in 1907 (Dike, 1982). The Methodist Mission established a hospital at Amachara in Umuahia in 1929.

The Roman Catholic Mission was not left behind in the pioneer medical work in the development of Nigeria. Fr. Lutz (1885-1900) was the pioneer Roman Catholic missionary in the establishment of Medical Services East of the Niger (Heerey in Agha, 2012). St. Luke's Hospital at Anua was opened in March 1933, while six dispensaries and four orphanages were established in Igboland, (Missionary Anuals, Vol. 17, 1935) the same year. Holy Rosary Maternity hospital was opened in Onitsha in 1935. The Mt. Carmel Hospital at Emekukwu was commissioned in 1935 (P.Falk:1997), Matter Misscricordia Hospital was established at Afikpo and Bishop Shanaham Hospital was established at Nsukka. Medical Services were carried on throughout Nigeria wherever the missionaries founded their church.

The establishment of hospitals also attracted the opening of Leper Colonies throughout the country. The Presbyterian mission opened a leper settlement at Itu in 1928, and another one at Uburu the same year. In 1939 the C.M.S. opened the Oji River Leper Settlement while the Methodist missionaries opened a leper colony at Uzualoli in 1930. Another leper colony was established at Garkida. In these settlements the lepers were not only cured, relieved and comforted, but they were also trained in carpentry and wood work. They were also taught how to mend shoes, work on palm oil press, Raffia weaving, fishing, and other trades, which helped to sustain them and their families. 


\section{Eradication of Obnoxious Cultural Practices}

The Christian missions did not only constitute a religious factor on its arrival in Nigeria, they also constituted a veritable socio-cultural force acting on the traditional life and practices which the people had lived and observed for many millennia before the advent of Christianity in the country. With such development, cultural changes became apparent in the country.

Before the advent of the Christian missions in many parts of the country, especially in the South, the natives were traditionally immersed in some obnoxious cultural practices. In those days, witchcraft, ritual murder, human sacrifice were common practices in Nigeria. The twins were victims of circumstance because they wee killed at birth or abandoned to die after birth. In many cases both the mother and the innocent twins suffered the same fate. The various missionary societies in Nigeria did not leave any stone unturned in their war against the evil cultural practices wherever they existed (Agha, 2012).

The Church Missionary Society, like other early European missionaries who came to Nigeria and Igboland in particular, trained their new converts to advance their evangelistic cause by fighting against all forms of idolatrous and obnoxious traditional and cultural life in any community they were engaged in (Okwueze, 1989). Such war was to be directed on virtually every aspect of the people's traditional practices including religious objects, system of worship, sacrifices and rituals, burial rites, secret religious cults, etc. The missionaries were especially out against religious and cultural forms of man's inhumanity-to-man that were meted on some members of the society in the name of religion and culture. These included human sacrifice, cult slavery and killing of twins. With the assistance of the colonial government, human sacrifice and killing of twins were stopped. Adherents of the traditional cults, oracles and shrines who insisted on continuing these obnoxious practices were reported to government agents who arrested and punished them severely while those who were already earmarked for such acts were liberated and protected by the government agents. Iyienu Hospital, Ogidi was particularly known as a place where twin babies were taken for protection through government assistance (Onyeidu, 2001). Some of the twins grew up to become national leaders, great politicians, scholars, and teachers in their various societies.

Also, the Christian missionaries were not comfortable with some tribal marriage laws and practices. They vehemently opposed some cultural laws and practices against women. Education was extended to the females. Girls were also admitted in schools. Today such obnoxious marriage laws and treatment against women are no more in existence. Women can now contribute effectively to the development of their communities and Nigeria in general.

Nevertheless, efforts to abolish cult slavery, known among the Igbos as osu caste system, proved abortive during the missionary days, especially among the Igbo. The so-called free-born continued to treat those who had the stigma of slavery hanging on them with contempt in many parts of Igboland until recently when State Governments began to grant such people autonomy as separate communities free from the so-called free-born.

\section{Development of Nigeria's Nationhood}

The above contributions of the Christian missions to the socio-economic development of the people of Nigeria invariably contributed in no small measure to the development of Nigeria's nationhood. Speaking on a similar subject, one of the greatest African leaders and protagonists of Ghana's independence, Kwame Nkrumah who was himself a former student of a Catholic Mission school adumbrated in a seminar shortly after the achievement of his Country's independence, "The rise of our country is properly due to the missionaries. To their work and their assistance I and others owe what we now are" (Pax Romana Seminar, 1957).

Certainly, most of the leading African nationals were educational products of the Christian missions. For Nigeria, these include Nnamdi Azikiwe, Obafemi Awolowo, Herbert Marcauley, Anthony Enahoro and a host of others. Without these Christian personalities the dream of having a 
sovereign Nigeria in 1960 would not have been realized. The development of the national politics of the country was also directly or indirectly the contribution of the Christian missions. The missionaries worked hand-in-glove with the British colonial administrators in Africa, and Nigeria in particular. With the gradual penetration of the Europeans and American missionaries into Africa, they began to attract other Europeans who felt that God has called them not only to colonize but also to civilize the natives. To this effect, originally, most African peoples saw no distinction between a missionary and a colonial official.

A Kikuyu proverb summarizes this fact thus: Gutiri mubea kana muthungu, meaning, "there is no priest and European: both are the same, the one like the other" (Onyebuagu, 2002). Thus, European colonial activities gradually progressed in Africa along with missionary work. This was especially so in Nigeria as a colony of the British government whose personnel were mostly Christians.

The British introduced modern politics in Nigeria through a gradual process of colonial administration. Between 1900 and 1960 the colonial masters established series of constitutions in Nigeria through their representatives such as Lord Luggard, Sir Hugh Clifford, etc. In response a Nigerian, a nationalist, a man who formed the first political party, Herbert Marcauley, a surveyor by profession, attacked the constitutions vigorously. His party Nigeria National Democratic Party was formed in 1923. After Clifford's Constitution was the Author Richard's of 1944 while that of Sir J ohn Macpherson came up in 1951. There was also the Oliver Lyttleton's Constitution of 1954 which marked the beginning of Federal system of government in Nigeria (Esedeke, 2001).

But earlier in 1953, a member of Parliament, Chief Anthony Enahoro had stunned the British by moving a motion that Nigeria should be self-governing by 1956 . Accordingly, in 1957, a Constitutional Conference was held in London from May $23^{\text {rd }}$ to June $26^{\text {th }}$ under the chairmanship of Allan Lennox-Boyd who made way for internal government for the Western and the Eastern Regions of Nigeria. The North was to achieve the same status in 1959 (Esedeke, 2001:60). On October 1, 1960, Nigeria became an independent nation.

The Anglican mission played a pioneering role in the national politics and also made substantial impact on local politics, especially in Southern Nigeria. In the words of Adediran (1994):

This however could be largely explained by the fact that unlike most other Christian denominations such as the Methodist, the Roman Catholic and the Baptist, the CMS (Anglicans) enjoyed a quasi-official status because it was usually associated with the agents of the British Government. Thus semi-official recognition was used to a great advantage by the (Anglican) church. Its agents - missionaries and converts made abundantly clear that they worked for the same goal with agents of the British Government and therefore had a sacred duty to interfere in politics. For these reasons, the church made attempts to control the indigenous ruling elite and influence the British agents. (p. 126)

This however was not the case in all parts of the country. In some places there was the collision of interests between the church and the colonial administrators and the administrators in such cases pursued lines of action independent of the church. This was for example the case in Northern Nigeria where until the 1930s the British officials preferred to fraternize with the Muslin leadership rather than the CMS Missionaries. Nevertheless, throughout the colonial era, the Anglican Church pressurized British officials to establish an administrative framework that would ensure a fruitful germination of Christian ideals which are usually development oriented (Adediran, 1994).

Thus the Nigerian politics gradually developed under the British colonial administration with some measure of influence from the missionaries and their products, especially those of the Church Missionary Society most of who were fellow British nationals with the colonial administrators. The subsequent democratic constitutions which evolved in the post-independent Nigeria to a great extent still have some subtle Christian undertone. This is one of the principal factors that underlie the often dissatisfaction and disaffection of the Muslims with democracy in the country. 


\section{Recommendations}

From the above findings, it has become necessary to make the following recommendations with the aim of challenging the present day church denominations in Nigeria to actually be committed to the task of furthering the Great Commission project - "Go therefore and make disciples of all nations, baptizing them...; teaching them..." (Mt. 28:19-20); casting out demons in the Lord's name...; and laying hands on the sick so that they will recover (Mk. 16: 17-18):

- The present day indigenous missionary movements should take over the task of real evangelization of the un-evangelized Nigerians, striving to reach the un-reached parts of the country and beyond with the Christian gospel so that they too may reap the benefits of Christian missions. They should not concentrate only in the cities where they look for other church's "sheep" (members) to steal and by so doing making merchandize of the gospel.

- The contemporary Christian missionary outfits of the various denominations in Nigeria should continue the good works of the European and American missionaries who pioneered the task of developing Nigeria socio-economically. The church of today should not leave the entire work of economic development of the nation to the government.

- Present day church leaders should not continue to run after government officials for material and financial donations. The church has unfortunately become too materialistic and this leads to the dilution of the gospel so as to please political office holders, and often time, to the failure to speak the truth in matters of social concerns. Pastors should commit themselves to the work of God's vineyard and allow God to provide for his work.

- The church should stop laying financial burdens on their members most of whom are poor beyond subsistent level. On the contrary, the present day church should take a clue from the charitable attitudes of the $19^{\text {th }}$ century Christian missions and begin to work towards empowering their members socio-economically instead of exploiting and impoverishing them.

- The church of today should develop more interest in politics not only in praying for successful elections but in active participation in partisan politics. In other words, the various church denominations in Nigeria should encourage their members to register into the membership of political parties and to participate actively in political activities so as to be able to bring Christian influence to bear in shaping national life and fostering national development.

\section{Conclusion}

The white missionaries who came to Nigeria in the $19^{\text {th }}$ century with their new religion from different parts of Europe and America contributed significantly to the growth and development of the country. As we have noted above, they bequeathed not only education and medical services but also other important aspects of development that touched the social, economic, political and moral life of Nigerians. The greater percentage of the food crops we enjoy today were introduced into Nigeria by the missionaries on their arrival. The introduction of foreign food crops, fruits, and vegetables has not only enriched Nigeria but has also been a source of good health and the growth of the population.

Western education has contributed so much to the social development of the nation both in terms of human development and physical transformation. It is some of such education-oriented developmental facilities that one of the militant Islamist sects in the country popularly known as Boko Haram is currently poised to annihilating.

Most of the northerners were not opportune to receive much of the missionary benefits owing to Muslim occupation of the North which led to the difficulty of the early Christian missions to penetrate the area. Due to Muslim domination of that part of the country the people lost the 
opportunity of reaping the numerous socio-economic benefits of the Christian missions, especially that of the Church Missionary Society whose early missionary outreach to Northern Nigeria was aborted as a result of Islamic opposition during the colonial era.

The few northerners who became Christians and have reaped the benefits of Christianity to some extent would have had a fuller and freer atmosphere for such harvests which by now would have meant consolidation of the socio-economic gains of Christianity in their areas were it not for the incessant persecutions they suffer under the Muslims. Nevertheless, majority of Nigerians have always valued Christian missions as an important socio-economic factor. Many $19^{\text {th }}$ and $20^{\text {th }}$ century missionaries are still being remembered today by their converts or their children with great affection for the socio-economic contributions they made in their lives.

\section{References}

Adediran, B. (1994) "The Church and Politics" in Omoyajowo, A. (ed.) The Anglican Church in Nigeria (1842-1992), Lagos: Macmillan Nigeria Publishers Ltd.

Adebiyi, P.A. (1994) "Anglican Church and Education" in Omoyajowo, A. (ed.) The Anglican Church in Nigeria (1842-1992), Lagos: Macmillan Nigeria Publishers Ltd.

Adiele, S.N. (1996) The Niger Mission - Origin, Growth and Impact, 1957-1995, Ikot-Ekpene: Clean Hands Productions.

(ed.) (2001) Anglican Church in Nigeria, Trends, Issues and Activities, Ikot Ekpene: Cleanhands Productions.

Agha, A.U. (1997) Early European Missions To West Africa, Enugu: Calvaryside Printing 7 Publishing Co., 1997, p.56.

Ajayi, J.F.A.(1965) Christian Missions in Nigeria, 1841-1891, Essex: Longmann.

Baur, J. (1998), 2000 Years of Christianity in Africa, Nairobi; Paulines Publications Africa.

Chatfield, A. (1998) Something In Common, Nothingham: John's Extension Studies.

Diara, B.C. (2003) Abbi Ugweke-Ugwunye in Church History - An Account of the Origin of Christianity in Abbi, Enugu: Computer Edge Publishers

(2009) "The Role of Christian Missions in the Socio-Economic Development of Africa (1800-1960)" in Nigerian Journal of Social Sciences, Vol 5 No. 1 Faculty of Social Sciences, UNN.

Dowley, T \& Co. eds. (1990) The History of Christianity, Oxford: A Lion Book.

Esedeke, E.A. (2000), Christians and Nigerian Politics, Aba: Effort Printers Nigeria.

Falk, P. (1997) The Growth of the Church in Africa, J os: Carpro Media.

Ilogu, E. (1974) Christianity and I gbo Culture, New York-London -Enugu: Nok Publishers Ltd.

Jones, E. (1952) "Church Missionary Intelligencer CMS., CA 1/0129" in A Mission to Niger, 1952.

Kalu, O.U. (1990-4) "Broken Conenant: Religious Change in Igbo Historiography" Neve Zeitschrift Furmissionwissenschaft, Separa, Abdruck.

Okafor, L. M. (1989) History of Nigeria, Onitsha: J oe Publishers (Nig.) Ltd.

Okeke, D.C. (1994) "The Church in Igboland" in Omoyajowo, J.A. (Ed.) The Anglican Church in Nigeria, Lagos: Macmillan Nigeria Publishers Ltd.

Onyeidu, S.O. (2001) Christianity and Onitsha Primal Society: The Anglican Contribution, Enugu: Magnet Ent.

Shelley, B.L. (1970). Church History in Plain Language, Taxas: World Book Publishers.

Tasie, G.O.M. (1978) "The Church in the Niger Delta" in Christianity in West Africa: The Nigerian Story, Ibadan: Daystar Press.

Walker, W. (1970) A History of the Christian Church, New York: Charles Scribner's Sons. 
